Jurnal_ep, Vol. 9 No. 2, Agustus 2019

\title{
ANALISIS DISKREPANSI PELAKSANAAN LAYANAN TUPOKSI BAGIAN DAN SUB BAGIAN DI LINGKUNGAN BIRO AKPK UNIVERSITAS PENDIDIKAN GANESHA SESUAI DENGAN PERMENRISTEKDIKTI NOMOR 14 TAHUN 2016
}

\author{
I Wayan Ariasa, Anak Agung Istri Ngurah Marheni, Ni Ketut Widiartini \\ Program Studi Penelitian dan Evaluasi Pendidikan, Pascasarjana \\ Universitas Pendidikan Ganesha \\ Singaraja, Indonesia \\ e-mail: ariasa.wayan@ymail.com,ngr.marhaeni@undiksha.ac.id,ketut.widiartini@undiksha.ac.id
}

\begin{abstract}
Abstrak
Penelitian ini bertujuan 1) untuk mengetahui dan mendeskripsikan diskrepansi pelaksanaan layanan tupoksi Bagian dan Sub Bagian di lingkungan Biro AKPK Universitas Pendidikan Ganesha sesuai dengan Permenristekdikti Nomor 14 Tahun 2016, 2) untuk mengetahui tingkat diskrepansi pelaksanaan layanan tupoksi Bagian dan Sub Bagian di lingkungan Biro AKPK Universitas Pendidikan Ganesha sesuai dengan Permenristekdikti Nomor 14 Tahun 2016. Penelitian ini menggunakan rancangan penelitian ex-post facto dengan populasi 35 orang pejabat struktural dan staf yang bertugas di rektorat pada Biro AKPK Universitas Pendidikan Ganesha. Jenis penelitian ini adalah penelitian deskriptif kuantitatif. Teknik pengambilan sampel menggunakan total sampling. Pengumpulan data dilakukan dengan kuesioner. Analisis data menggunakan statistik non-parametrik yaitu Uji Jenjang - Bertanda Wilcoxon. Hasil analisis data menunjukkan secara keseluruhan terdapat diskrepansi/kesenjangan dengan kategori Sangat Kecil (SK) dengan persentase skor ratarata sebesar $92,06 \%$, dan besar beda $-7,93$, bertanda negatif (-) pada pelaksanaan layanan tupoksi Bagian dan Sub Bagian di lingkungan Biro AKPK Universitas Pendidikan Ganesha sesuai dengan Permenristekdikti Nomor 14 Tahun 2016.
\end{abstract}

Kata kunci: diskrepansi, layanan, tupoksi

\section{Abstract}

This study aimed at 1) to find out and describe the discrepancy in in the services implementation of Tupoksi Section and Sub Division in the AKPK Bureau at Ganesha University of Education in accordance with Permenristekdikti No. 14 of 2016 ,2) determining discrepancy and degree of discrepancy in the services implementation of Tupoksi Section and Sub Division in the AKPK Bureau at Ganesha University of Education in accordance of Permenristekdikti Number 14 of 2016. The study used an ex-post facto study design with a population of 35 structural officials and on duty staff of AKPK Bureau at the rectorat in Ganesha University of Education. This research was quantitative descriptive research. The sampling technique used total sampling. Data collection was done by questionnaire. Data analysis used non-parametric statistics namely Level Test - Signed Wilcoxon. The results of data analysis showed that overall there was a discrepancy / gap with the Very Small (SK) category with an average score score of $92.22 \%$, and a large percentage difference of $7.77 \%$, marked negative (-) in the implementation of Tupoksi Section and Sub Division in the AKPK Bureau at Ganesha University of Education in accordance with Permenristekdikti Number 14 of 2016.

Key words: discrepancy, service, tupoksi 


\section{PENDAHULUAN}

Pegawai Negeri Sipil (PNS) menurut Undang-Undang Nomor 43 Tahun 1999 pasal 1 adalah keseluruhan upaya untuk meningkatkan efisiensi, efektifitas, dan derajat profesionalisme penyelenggaraan tugas, fungsi, dan kewajiban kepegawaian yang meliputi perencanaan, pengadaan, pengembangan kualitas penempatan, promosi, penggajian, kesejahteraan, dan pemberhentian.

Dalam perjalanan Undiksha selama 10 Tahun (2006-2016) banyak hal telah berubah secara internal. Oleh karena itu, Undiksha dipandang perlu untuk mengembangkan visi dan misinya agar dapat berperan aktif dalam memajukan pendidikan di tanah air dan mengikuti perkembangan masyarakat dunia pada era global. Salah satu perubahan signifikan Undiksha yang terjadi pada Tahun 2016 adalah perubahan Organisasi dan Tata Kerja (OTK) baru yang ditetapkan melalui Peraturan Menteri Riset, Teknologi, dan Pendidikan Tinggi (Permenristekdikti) Republik Indonesia Nomor 14 Tahun 2016.

Dalam Pasal 3 Permenristekdikti Nomo 14 Tahun 2016, disebutkan bahwa Universitas Pendidikan Ganesha sebagai perguruan tinggi memiliki organ yang terdiri atas : (a) Senat, (b) Rektor, (3) Satuan Pengawas Internal, (4) Dewan Pertimbangan. Kemudian lebih jauh dijelaskan pada Pasal 6 bahwa Rektor sebagai organ pengelola terdiri atas : (a) Rektor dan Wakil Rektor, (2) Biro, (3) Fakultas dan Pascasarjana, (4) Lembaga, (5) Unit Pelaksana Teknis.

Hasil penelitian Mulyadi dalam Abubakar (2018) membuktikan bahwa variabel kompetensi memiliki pengaruh yang positif dan cukup signifikan terhadap tingkat produktivitas kerja pegawai.

Selain itu, hasil penelitian Wasti dalam Abubakar (2018) juga membuktikan bahwa variabel kompetensi memiliki pengaruh yang positif tetapi tidak signifikan terhadap produktivitas kerja pegawai.

Hasil penelitian Abubakar (2018) tentang Pengaruh Kompetensi Pegawai Terhadap Produktivitas Kerja Pegawai Dinas Kesehatan Kota Bandung. Hasil analisis uji kontribusi pengaruh, menunjukkan bahwa variabel kompetensi berpengaruh terhadap produktivitas kerja pegawai sebesar $68,9 \%$.

Hasil penelitian yang dilakukan oleh Dantes, dkk (2013) tentang Analisis Eksploratoris Kebijakan Pengembangan dan Pembinaan Kepegawaian Universitas Pendidikan Ganesha menunjukkan bahwa spesifikasi personal pgawai dalam kaitannya dengan organisasi Universitas Pendidikan Ganesha dalam tatanan organisasi menduduki posisi yang strategis.

Landrum, Prybutok, Zhang, \& Peak (2009) mengembangkan dimensi servqual dalam mengukur kualitas jasa adalah sebagai berikut: 1) item yang digunakan untuk mengukur tangibles mengacu pada fasilitas fisik, peralatan, dan personil; 2) item yang digunakan untuk mengukur reliabilitas mengacu pada kemampuan perusahaan untuk melakukan layanan yang dijanjikan, relevan dan akurat; 3) item yang digunakan untuk mengukur responsiveness adalah keinginan untuk membantu pelanggan dan kerelaan memberikan layanan; 4) item yang digunakan untuk mengukur assurance adalah kemampuan karyawan untuk menginspirasi kepercayaan dan keyakinan konsumen dengan pengetahuan, keterampilan dan sikap (kopetensi) yag dimiliki dan 5) item yang digunakan untuk mengukur emphati mengacu pada kepedulian dan perhatian yang diberikan kepada pelanggan.

Kata discrepancy berarti kesenjangan, model ini menurut Madaus, Sriven \& Stufflebeam (1993: 79-99) berangkat dari asumsi bahwa untuk mengetahui kelayakan suatu program, evaluator dapat membandingkan antara apa yang seharusnya diharapkan terjadi (standar) dengan apa yang sebenarnya terjadi (performance). Dengan membandingkan kedua hal tersebut, maka dapat diketahui ada tidaknya kesenjangan (discrepancy), yaitu standar yang ditetapkan dengan kinerja yang sesungguhnya. Sedangkan Arikunto dan Jabar, (2008:48) menyatakan bahwa model diskrepansi mengukur adanya kesenjangan/perbedaan antara yang 
seharusnya dicapai dengan yang sudah riil dicapai.

Sedangkan Wirawan (2011: 106) menyebutnya dengan istilah The Discrepancy Evaluation Model sebagai Model Evaluasi Ketimpangan, yang menekankan bahwa evaluasi merupakan suatu seni (arts) melukiskan ketimpangan antara standar kinerja dengan kinerja yang terjadi.

Model Diskrepansi dikembangkan oleh Malcolm Provus yang menekankan pada adanya kesenjangan di dalam pelaksanaan program. Evaluasi pada model ini mengukur adanya perbedaan antara yang seharusnya dicapai dengan apa yang riil dicapai (senyatanya). Sehingga hakekat evaluasi model diskrepansi adalah untuk mengetahui tingkat kesesuaian antara standar yang sudah ditentukan dalam program dengan penampilan aktual dari program. Standar dimaksud berupa kriteria yang telah dikembangkan dan ditetapkan dengan hasil efektif. Sedangkan penampilan yaitu sumber daya, prosedur, manajemen dan hasil nyata yang tampak ketika program dilaksanakan.

Marhaeni (2012:158) mengemukakan ada enam kategori kesenjangan yang dapat dinilai pada program pendidikan, antara lain. (1) Kesenjangan antara rencana dan pelaksanaan program. (2) Kesenjangan antara yang diduga atau diramalkan dengan hasil yang diperoleh. (3) Kesenjangan antara status kemampuan peserta didik yang ada dengan standar kemampuan yang sudah ditentukan (need assessment). (4) Kesenjangan tujuan. (5) Kesenjangan mengenai bagian program yang dapat diubah. (6) Kesenjangan dalam sistem yang tidak konsisten.

\section{METODE}

Jenis penelitian ini adalah penelitian deskriptif kuantitatif, dengan teknik pengambilan sampelnya adalah total sampling.

Penelitian ini menggunakan metode pengumpulan data berupa non-tes yaitu dengan metode kuesioner/angket, dan metode analisis data yang digunakan adalah analisis statistik nonparametrik dengan teknik Uji Jenjang - Bertanda Wilcoxon.

\section{HASIL DAN PEMBAHASAN}

Penelitian ini melibatkan 35 orang pejabat struktural dan staf yang bertugas di rektorat Universitas Pendidikan Ganesha untuk memperoleh data tentang pelaksanaan layanan Tupoksi Bagian dan Sub Bagian di lingkungan Biro AKPK, yang terdiri dari 1 orang Kepala Biro, 3 orang Kepala Bagian, 9 orang Kepala Sub Bagian, 4 orang staf pada Bagian Akademik dan Statistik, 8 orang Staf pada Bagian Kemahasiswaan dan Humas, 10 orang Staf pada Bagian Perencanaan dan Kerjasama. Data yang dikumpulkan dalam penelitian ini difokuskan pada pelaksanaan layanan Tupoksi Bagian dan Sub Bagian di Lingkungan Biro AKPK Universitas Pendidikan Ganesha sesuai dengan Permenristekdikti Nomor 14 Tahun 2016.

Sesuai dengan perumusan masalah penelitian ini, adapun hasil data tentang Diskrepansi Pelaksanaan Layanan Tupoksi Bagian dan Sub Bagian di lingkungan Biro AKPK Universitas Pendidikan Ganesha sesuai dengan Permenristekdikti Nomor 14 Tahun 2016, dapat disajikan pada tabel berikut.

Tabel 1. Rekapitulasi Hasil Analisis Data Pelaksanaan Layanan Tupoksi Bagian dan Sub Bagian di lingkungan Biro AKPK Universitas Pendidikan Ganesha sesuai dengan Permenristekdikti Nomor 14 Tahun 2016 


\begin{tabular}{|c|c|c|c|c|c|c|c|c|}
\hline \multirow{2}{*}{ No } & \multirow{2}{*}{ Jabatan } & \multirow{2}{*}{ 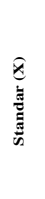 } & \multirow{2}{*}{ 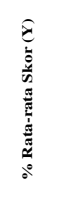 } & \multirow{2}{*}{ 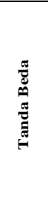 } & \multirow{2}{*}{ 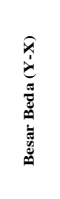 } & \multicolumn{2}{|c|}{ 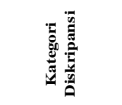 } & \multirow{2}{*}{ 产 } \\
\hline & & & & & & 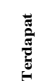 & 思 & \\
\hline 1 & \begin{tabular}{|l} 
Kepala Bajain \\
Akademik dan \\
Statistik
\end{tabular} & 100 & 79,5 & - & $-20,5$ & $\checkmark$ & & $\mathrm{K}$ \\
\hline 2 & \begin{tabular}{|l|} 
Kepala Bagian \\
Kemahasiswaan dan \\
Humas
\end{tabular} & 100 & 96,92 & . & $-3,08$ & $\sqrt{ }$ & & $\mathrm{sk}$ \\
\hline 3 & \begin{tabular}{|l|} 
Kepala Bagian \\
Perencanaan dan \\
Kerjasama
\end{tabular} & 100 & 88 & - & -12 & $\sqrt{ }$ & & SK \\
\hline 4 & \begin{tabular}{|l}
$\begin{array}{l}\text { Kepala Sub Bagian } \\
\text { Registrasi dan } \\
\text { Statistika }\end{array}$ \\
\end{tabular} & 100 & 99,33 & . & $-0,67$ & $\sqrt{ }$ & & SK \\
\hline 5 & \begin{tabular}{|l} 
Keppala Sub Bagian \\
Sarana Akademik
\end{tabular} & 100 & 96 & . & -4 & $\checkmark$ & & $\mathrm{SK}$ \\
\hline 6 & \begin{tabular}{|l} 
Kepala Sub Bagian \\
Akademik dan \\
evaluasi
\end{tabular} & 100 & 98 & . & -2 & $\checkmark$ & & $\mathrm{sk}$ \\
\hline 7 & 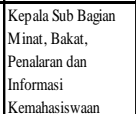 & 100 & 85,55 & . & $-14,44$ & $\checkmark$ & & SK \\
\hline 8 & \begin{tabular}{|l|}
$\begin{array}{l}\text { Kepala Sub Bagian } \\
\text { Kesejahteraan dan } \\
\text { Alummi }\end{array}$ \\
\end{tabular} & 100 & 97,57 & - & $-2,4$ & $\checkmark$ & & SK \\
\hline 9 & \begin{tabular}{|l|}
$\begin{array}{l}\text { Kepplal Sub Bagian } \\
\text { Hubungan } \\
\text { Masyarakat }\end{array}$ \\
\end{tabular} & 100 & 96 & - & -4 & $\checkmark$ & & $\mathrm{sK}$ \\
\hline 10 & 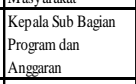 & 100 & 90,5 & . & $-9,5$ & $\sqrt{ }$ & & SK \\
\hline 11 & \begin{tabular}{|l} 
Keppala Sub Bagan \\
Evaluasi Pelaksana \\
Program dan Angegan
\end{tabular} & 100 & 84,29 & & $-15,7$ & $\sqrt{ }$ & & SK \\
\hline 12 & \begin{tabular}{|l|}
$\begin{array}{l}\text { Kepala Sub Bagian } \\
\text { Kerisama }\end{array}$ \\
\end{tabular} & 100 & 93,08 & . & $-6,92$ & $\checkmark$ & & SK \\
\hline & Jumlah & 1200 & 1104,74 & - & $.95,21$ & & & \\
\hline & Rerata & 100 & 92,06 & 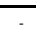 & $.7,93$ & & & \\
\hline
\end{tabular}

Secara keseluruhan (total) hasil dari analisis pelaksanaan layanan tupoksi Kepala Bagian dan Sub Bagian di lingkungan Biro AKPK Universitas Pendidikan Ganesha sesuai dengan Permenristekdikti Nomor 14 Tahun 2016, bahwa persentase skor rata-rata yang diperoleh adalah sebesar 92,06 \%, dan besar beda -7,93 serta tanda beda negatif (-). Hal ini menunjukkan bahwa kondisi nyata (riil) layanan tupoksi belum dapat mencapai standar (kondisi ideal). Hal ini berarti bahwa terdapat diskrepansi/kesenjangan dengan kategori Sangat Kecil (SK) pada pelaksanaan layanan tupoksi Kepala Bagian dan Sub Bagian di lingkungan Biro AKPK Universitas Pendidikan Ganesha sesuai dengan Permenristekdikti Nomor 14 Tahun 2016.

Hasil itu menunjukkan bahwa Kepala Bagian dan Kepala Sub Bagian di lingkungan Biro AKPK Universitas Pendidikan Ganesha belum dapat mencapai standar yang telah ditetapkan dalam Permenristekdikti Nomor 14 Tahun
2016. Hal ini disebabkan oleh beberapa faktor:

Pertama, Sumber Daya Manusia (SDM), karena sumber daya manusia merupakan pelaku dari keseluruhan tingkat mulai dari perencanaan sampai dengan evaluasi yang mampu memanfaatkan sumber daya lainnya yang dimiliki oleh organisasi. Dalam suatu organisasi, sumber daya manusia merupakan aset yang sangat penting dan berpengaruh terhadap berjalannya roda organisasi. Peranan sumber daya manusia sebagai variabel individu akan mempengaruhi perilaku dan prestasi kerja atau kinerja.

Kinerja pegawai haruslah dijadikan indikator penting dalam pencapaian tujuan organisasi. Kinerja pegawai yang baik akan memberikan iklim yang baik bagi keberlangsungan organisasi. Menurut Mangkunegara (2006) kinerja adalah hasil kerja secara kualitas dan kuantitas yang dicapai seorang pegawai dalam melaksanakan tugasnya sesuai tanggungjawab yang diberikan kepadanya.

Kinerja pegawai di lingkungan Universitas Pendidikan Ganesha dalam penelitian ini adalah prestasi atau hasil kerja pegawai di lingkungan Universitas Pendidikan Ganesha selama periode tertentu sesuai dengan tugas dan fungsinya dalam mencapai tujuan lembaga yang didasarkan atas kecakapan, pengalaman dan kesungguhan serta waktu yang ditunjukkan dengan (1) kualitas kerja, (2), kecepatan/ketepatan kerja, (3) inisiatif dalam bekerja, (4) kemampuan dalam bekerja, dan (5) kemampuan mengkomunikasikan pekerjaan di lingkungan Universitas Pendidikan Ganesha.

Terkait dengan kualitas kerja pegawai di lingkungan Universitas Pendidikan Ganesha yang berada dalam kategori kurang bagus, data empirik membuktikan bahwa masih banyak adanya pegawai yang tergolong baru di bidangnya. Selain itu ada beberapa faktor yang mempengaruhi kinerja pegawai yaitu faktor individu dan faktor situasi kerja.

Temuan di atas didukung oleh pendapat Gibson et.al dalam Srimulyo (1999: 39) yang menyatakan bahwa ada 
tiga tingkat perangkat variabel yang mempengaruhi perilaku dan prestasi kerja atau kinerja, yaitu : 1) variabel individu, yang terdiri dari : a) kemampuan dan keterampilan : mental dan fisik, b) latar belakang : keluarga, tingkat sosial, penggajian, c) demografis : umur, asal usul, jenis kelamin. 2) variabel organisasional, terdiri dari: a) sumber daya, b) kepemimpinan, c) imbalan, d) struktur, e) desain pekerjaan. 3) variabel psikologis, yang terdiri dari: a) persepsi, b) sikap, c) keperibadian, d) belajar, dan e) motivasi.

Sejalan dengan temuan Gibson (1999), Tiffin dan Mc. Cormick (dalam Srimulyo, 1994: 40) mengemukakan bahwa terdapat dua variabel yang mempengaruhi kinerja, yaitu: (1) variabel individual, terdiri atas : sikap, karakteristik, sifat-sifat fisik, minat dan motivasi, pengalaman, umur, dan jenis kelamin, pendidikan, serta faktor individual lainnya. (2) variabel situasional, meliputi: a) faktor fisik dan pekerjaan (metode kerja, kondisi dan desain perlengkapan kerja, penataan ruangan, lingkungan fisik, b) faktor sosial dan organisasi (peraturan-peraturan organisasi, sifat organisasi, jenis latihan dan pengawasan, sistem upah dan lingkungan sosial).

Terkait dengan temuan Gibson (1999), dibuktikan pula melalui penelitian yang dilakukan oleh Anggraeni (2011) tentang Pengaruh Kemampuan dan Motivasi Terhadap Kinerja Pegawai Pada Sekolah Tinggi Seni Indonesia (STSI) Bandung.

Berdasarkan hasil kuesioner dengan para pegawai pada Sekolah Tinggi Seni Indonesia (STSI) Bandung yang dijadikan sebagai responden, maka persepsi pegawai dapat terungkap mengenai kemampuan (Ability) dalam melaksanakan pekerjaan berdasarakan jawaban atas pertanyaan mengenai: pengetahuan pegawai dalam bekerja, keahlian pegawai dalam bekerja, keterampilan pegawai dalam bekerja, dan sikap serta perilaku pegawai dalam bekerja.

Hal ini sesuai dengan pendapat yang dikemukakan oleh As'ad dalam Anggraeni (2011) bahwa kemampuan pada individu merupakan pengetahuan, intelegensia dan manual skill yang dimiliki oleh pegawai Sekolah Tinggi Seni Indonesia (STSI) Bandung dapat mendorong efektifitas kerja para pegawai, sehingga para pegawai bekerja sesuai dengan pengetahuan tentang pelaporan.

Keseluruhan kemampuan individual personil pada hakekatnya dibentuk oleh sifat-sifat dan kemampuan-kemampuan yang dikemukakan oleh J. Winardi dalam Anggraeni (2011) bahwa salah satu akibat langsung dari sifat kemampuan yang harus dimiliki oleh setiap organisator harus terus memupuk "inisiatif". Sedangkan Lowser dan Poter mendefinisikan kemampuan sebagai karakteristik individual seperti intelegensia, manual skill, traits yang merupakan kekuatan potensial seseorang untuk berbuat dan sifatnya stabil (As'ad, 2000: 61).

Kemampuan pada induvidu tersebut paling tidak ditentukan oleh tiga aspek kondisi dasar, yaitu: kondisi sensoris dan kognitif, pengetahuan tentang cara respon yang benar, dan kemampuan melaksanakan respon tersebut. Pengaruh keahlian terhadap hasil kerja termasuk kategori sangat baik. Salah satu kinerja dapat dikatakan optimal bila pekerjaan dapat dilakukan secara profesional dan proporsional, dengan kata lain "The Right Man on The Right Job" sesuai dengan kemampuan, keterampilan dan keahliannya. Sebagaimana dikemukakan oleh Siagian (2008: 109) bahwa keterampilan dan keahlian sumber daya manusia penting bagi organisasi dan masyarakat yang tidak boleh diabaikan agar ketepatan menyelesaikan pekerjaannya, sehingga gairah kerja dan kedisiplinannya akan lebih baik terhadap hasil kerja.

Kedua, Kompetensi.

Secara general, kompetensi dapat dipahami sebagai sebuah kombinasi antara keterampilan (skill), atribut personal, dan pengetahuan (knowledge) yang tercermin melalui perilaku kinerja (job behaviour) yang dapat diamati, diukur, dan dievaluasi.

Setidaknya ada lima (5) karakteristik yang membentuk kompetensi, yakni : (1) 
faktor pengetahuan meliputi masalah teknis, administratif, proses kemanusiaan, dan sistem; (2) keterampilan (skill); merujuk pada kemampuan seseorang untuk melakukan suatu kegiatan; (3) konsep diri dan nilai-nilai ; merujuk pada sikap, nilai-nilai dan citra diri seseorang; (4) karakterstik pribadi ; merujuk pada karakteristik fisik dan konsistensi tanggapan terhadap situasi atau informasi; (5) motif ; merupakan emosi, hasrat, kebutuhan psikologis atau dorongandorongan lain yang memicu tindakan.

Hasil penelitian Mulyadi dalam Abubakar (2018) membuktikan bahwa variabel kompetensi memiliki pengaruh yang positif dan cukup signifikan terhadap tingkat produktivitas kerja pegawai. Dalam penelitiannya diuraikan bahwa kompetensi melalui indikator prestasi, melayani, memimpin, mengelola, berfikir, dan keperibadian yang efektif memiliki pengaruh terhadap tingkat produktivitas kerja sebesar $48,71 \%$ yang mana pengaruh ini termasuk ke dalam kategori sedang.

Selain itu hasil penelitian Wasti dalam Abubakar (2018) juga membuktikan bahwa variabel kompetensi memiliki pengaruh yang positif tetapi tidak signifikan terhadap produktivitas kerja pegawai. Dalam penelitiannya diuraikan bahwa kompetensi melalui sub variabel kemampuan personal, kemampuan mengelola perubahan, dan kemampuan mengelola budaya kerja memiliki pengaruh sebesar $16,3 \%$ yang mana pengaruh ini termasuk ke dalam kategori kecil.

Terkait dengan hasil penelitian di atas, dilakukan penelitian oleh Abubakar (2018) tentang Pengaruh Kompetensi Pegawai Terhadap Produktivitas Kerja Pegawai Dinas Kesehatan Kota Bandung.

Berdasarkan hasil analisis uji kontribusi pengaruh, menunjukkan bahwa variabel kompetensi berpengaruh terhadap produktivitas kerja pegawai sebesar 0,689 atau $68,9 \%$. Kompetensi pegawai terdiri dari komponen sikap, pengetahuan, dan keterampilan berpengaruh sangat kuat terhadap produktivitas kerja pegawai yang terdiri dari faktor pelatihan, mental dan kemampuan karyawan, dan hubungan antar bawahan dan atasan.

Kompetensi pegawai merupakan salah satu bagian penting dalam memudahkan pencapaian tujuan organisasi. Banyak fakta menunjukkan adanya kegagalan yang dialami oleh suatu organisasi disebabkan salah satunya oleh lemahnya faktor kompetensi. Hal ini mengandung makna bahwa produktivitas kerja yang dicapai oleh para pegawai secara empirik memang membutuhkan kompetensi yang mumpuni, sehingga para pegawai benar-benar dapat melaksanakan tugas pokok dan fungsinya sesuai dengan prosedur yang telah ditetapkan. Munculnya kesenjangan antara realisasi kerja dengan target yang telah ditetapkan disebabkan oleh ketidakmampuan pegawai dalam memahami job description, dengan demikian dapat dikatakan bahwa kompetensi pegawai merupakan hal penting dalam wadah organisasi atau lembaga dalam pencapaian tujuan organisasi.

Namun tingkat keberhasilan kompetensi pegawai dalam meningkatkan produktivitas kerja pegawai tidak hanya ditentukan oleh pemahaman pegawai terhadap job description tetapi juga ditentukan oleh adanya penerapan komponen-komponen yang terkait dengan kompetensi pegawai itu sendiri. Hal tersebut dapat dimengerti, karena implementasi dari komponen-komponen kompetensi pegawai sesungguhnya merupakan faktor kunci dalam memahami job description secara utuh.

Hal ini sejalan dengan teori yang dikemukakan oleh Wibowo dalam Abubakar (2018) yaitu kompetensi merupakan suatu kemampuan untuk melaksanakan suatu pekerjaan yang dilandasi atas keterampilan dan pengetahuan serta didukung oleh sikap kerja yang dituntut oleh pekerjaan tersebut.

Hasil penelitian yang dilakukan oleh Dantes, dkk (2013) tentang Analisis Eksploratoris Kebijakan Pengembangan dan Pembinaan Kepegawaian Universitas Pendidikan Ganesha, menunjukkan bahwa kualitas kerja pegawai di lingkungan Universitas Pendidikan Ganesha baik yang 
dinilai oleh pejabat, atasan, maupun bawahan berada pada kategori cukup.

Ketiga, Budaya Organisasi.

Menurut Harber et al (1997), budaya organisasi dikenal luas sebagai fondasi sistem dan aktivitas manajemen dalam setiap organisasi. Budaya organisasi dipandang sebagai nilai-nilai bersama dan norma-norma perilaku yang diyakini dan dianut oleh anggota organisasi. Nilai dan norma tersebut menciptakan pendekatan yang digunakan anggota organisasi dalam melaksanakan pekerjaan dan mengatasi permasalahan yang dihadapi. Menurut Abdul Rashid et al (2003), banyak pakar menyebutkan bahwa budaya organisasi dapat menjadi basis adaptasi dan kunci keberhasilan organisasi sehingga banyak penelitian dilakukan untuk mengidentifikasi nilai-nilai atau norma-norma perilaku yang bisa memberikan kontribusi besar bagi keberhasilan organisasi.

Keempat, Kepemimpinan.

Menurut Locander et al (2002), kepemimpinan (leadership) secara umum didefinisikan sebagai hubungan antara pimpinan (leader) dengan yang dipimpin (follower). Lebih lanjut dijelaskan bahwa kepemimpinan mengandung makna pemimpin mempengaruhi yang dipimpin tapi hubungan antara pemimpin dengan yang dipimpin bersifat saling menguntungkan kedua belah pihak. Lok dan Crawford (2001) memandang kepemimpinan sebagai sebuah proses mempengaruhi aktivitas suatu organisasi dalam upaya menetapkan dan mencapai tujuan.

\section{PENUTUP \\ Simpulan}

Berdasarkan hasil analisis data pada penelitian ini dapat disimpulkan.
1) Bahwa
terdapat
diskrepansi/

kesenjangan kategori kecil (K) dengan persentase skor rata-rata adalah sebesar $79,50 \%$ dengan besar beda 20,50 dan tanda beda negatif (-) pada pelaksanan layanan tupoksi Kepala Bagian Akademik dan Statistik ditinjau dari Permenristekdikti Nomor 14 Tahun 2016.

2) Bahwa terdapat diskrepansi/ kesenjangan kategori sangat kecil (SK) dengan persentase skor rata-rata yaitu sebesar 96,92 \% dengan besar beda 3,08 dan tanda beda negatif (-) pada pelaksanan layanan tupoksi Kepala Bagian Kemahasiswan dan Humas ditinjau dari Permenristekdikti Nomor 14 Tahun 2016.

3) Bahwa terdapat diskrepansi/ kesenjangan kategori sangat kecil (SK) dengan persentase skor rata-rata yaitu sebesar $88 \%$ dengan besar beda -12 dan tanda beda negatif (-) pada pelaksanan layanan tupoksi Kepala Bagian Perencanaan dan Kerjasama ditinjau dari Permenristekdikti Nomor 14 Tahun 2016.

4) Bahwa terdapat diskrepansi/ kesenjangan kategori sangat kecil (SK) dengan persentase skor rata-rata yaitu sebesar 99,33\% dengan besar beda 0,67 dan tanda beda negatif (-) pada pelaksanan layanan tupoksi Kepala Sub Bagian Registrasi dan Statistik ditinjau dari Permenristekdikti Nomor 14 Tahun 2016.

5) Bahwa terdapat diskrepansi/ kesenjangan kategori sangat kecil (SK) dengan persentase skor rata-rata yaitu sebesar $96 \%$ dengan besar beda -4 dan tanda beda negatif (-) pada pelaksanan layanan tupoksi Kepala Sub Bagian Sarana Akademik ditinjau dari Permenristekdikti Nomor 14 Tahun 2016.

6) Bahwa terdapat diskrepansi/ kesenjangan kategori sangat kecil (SK) dengan persentase skor rata-rata yaitu sebesar $98 \%$ dengan besar beda -2 dan tanda beda negatif (-) pada pelaksanan layanan tupoksi Kepala Sub Bagian Akademik dan Evaluasi ditinjau dari Permenristekdikti Nomor 14 Tahun 2016.

7) Bahwa terdapat diskrepansi/ kesenjangan kategori sangat kecil (SK) dengan persentase skor rata-rata yaitu sebesar 85,56 \% dengan besar beda 14,44 dan tanda beda negatif (-) pada pelaksanan layanan tupoksi Kepala Sub Bagian Minat, Bakat, Penalaran, dan Informasi Kemahasiswaan ditinjau dari Permenristekdikti Nomor 14 Tahun 2016.

8) Bahwa terdapat diskrepansi/ kesenjangan kategori sangat kecil (SK) dengan persentase skor rata-rata yaitu 
sebesar $97,58 \%$ dengan besar beda 2,42 dan tanda beda negatif (-) pada pelaksanan layanan tupoksi Kepala Sub Bagian Kesejahteraan Mahasiswa dan Alumni ditinjau dari Permenristekdikti Nomor 14 Tahun 2016.

9) Bahwa terdapat diskrepansi/ kesenjangan kategori sangat kecil (SK) dengan persentase skor rata-rata yaitu sebesar $96 \%$ dengan besar beda -4 dan tanda beda negatif (-) pada pelaksanan layanan tupoksi Kepala Sub Bagian Hubungan Masyarakat ditinjau dari Permenristekdikti Nomor 14 Tahun 2016.

10) Bahwa terdapat diskrepansi/ kesenjangan kategori sangat kecil (SK) dengan persentase skor rata-rata yaitu sebesar 90,50 \%. dengan besar beda 9,50 dan tanda beda negatif $(-)$ pada pelaksanan layanan tupoksi Kepala Sub Bagian Program dan Anggaran ditinjau dari Permenristekdikti Nomor 14 Tahun 2016.

11) Bahwa terdapat diskrepansi/ kesenjangan kategori sangat kecil (SK) dengan persentase skor rata-rata yaitu sebesar $84,29 \%$. dengan besar beda $-15,70$ dan tanda beda negatif (-) pada pelaksanan layanan tupoksi Kepala Sub Bagian Evaluasi Pelaksanaan Program dan Anggaran ditinjau dari Permenristekdikti Nomor 14 Tahun 2016.

12) Bahwa terdapat diskrepansi/ kesenjangan kategori sangat kecil (SK) dengan persentase skor rata-rata yaitu sebesar 93,08 \%. dengan besar beda $-6,92$ dan tanda beda negatif $(-)$ pada pelaksanan layanan tupoksi Kepala Sub Bagian Kerjasama ditinjau dari Permenristekdikti Nomor 14 Tahun 2016.

\section{Saran}

Dari hasil penelitian yang diperoleh menunjukkan bahwa layanan tupoksi Bagian dan Sub Bagian di lingkungan Biro AKPK Universitas Pendidikan Ganesha terdapat diskrepansi/kesenjangan dengan kategori Kecil (K) dan Sangat Kecil (SK) ditinjau dari Permenristekdikti Nomor 14 Tahun 2016. Oleh karena itu dapat disarankan hal-hal sebagai berikut.
1) Para Kepala Bagian dan Sub Bagian di lingkungan Biro AKPK mulai membangun komitmen untuk melaksanakan tupoksi sesuai standar acuan yaitu Permenristekdikti Nomor 14 Tahun 2016

2) Para Kepala Bagian dan Sub Bagian di lingkungan Biro AKPK hendaknya selalu berusaha menambah wawasan secara teoretis, yuridis, dan praktis

3) Para Kepala Bagian dan Sub Bagian di lingkungan Biro AKPK hendaknya tanpa henti membangun komitmen untuk terus meningkatkan kinerja dalam upaya peningkatan kualitas tupoksi

4) Para Kepala Bagian dan Sub Bagian di lingkungan Biro AKPK tanpa hentihentinya meningkatkan komitmen diri untuk menjadi tenaga kependidikan yang professional

5) Diharapkan agar sosialisasi mengenai tupoksi sesuai dengan Permenristekdikti Nomor 14 Tahun 2016 dilakukan secara berkala.

6) Diharapkan agar monitoring internal dilakukan baik secara terencana maupun secara insidental

7) Kepada peneliti lain diharapkan mengembangkan penelitian ini pada lokasi lain dengan sampel yang lebih banyak dan melakukan pengembangan instrumen yang lebih kompleks lagi.

\section{DAFTAR RUJUKAN}

Abubakar, R.R.T. (2018). Pengaruh Kompetensi Pegawai terhadap Produktivitas Kerja Pegawai Dinas Kesehatan Kota Bandung. Jurnal Administrasi Negara, Volume 24 No 1, April 2018. diakses tanggal 26 Juni 2019

Anggraeni, N. (2011). Pengaruh Kemampuan dan Motivasi terhadap Kinerja Pegawai pada Sekolah Tinggi Seni Indonesia (STSI) Bandung. Jurnal Penelitian Pendidikan Volume 12 No 2, Oktober 2011. diakses tanggal 22 Juni 2019 
Arikunto, S., \& Cepi, S. (2008). Evaluasi Program Pendidikan. Jakarta : Bumi Aksara.

Dantes, N., \& Dantes, R. (2017). Statistika Nonparametrik. Singaraja : Undiksha Press.

Dantes, N., Natajaya, I.N., Yudana, I.M., Sunu, I.G.K.A., \& Dantes, K.R. (2013). Analisis Eksploratoris Kebijakan Pengembangan dan Pembinaan Kepegawaian Universitas Pendidikan Ganesha. Singaraja : Laporan Penelitian Institusional Kebijakan Institusi.

Darojat., \& Wahyudhiana, M. (2015). Model Evaluasi Program Pendidikan. Jurnal Islamadina, Volume XIV, No.1, Maret 2015 : 1-28. Retrieved from https://media.neliti.com/media/publica tions/135691-ID-model-evaluasiprogram-pendidikan.pdf diakses Tanggal 04 Februari 2019

Harber, D.G., Ashkanasy, N.M., \& Callan, V.J (1997). Implementing quality service in a public hospital setting: A path-analytic study of the organizational antecedents of employee perceptions and outcomes, Public Productivity \& Management Review, Vol. 21, No. 1, pp. 13-29

Landrum, H., Prybutok, V., Zhang, X., \& Peak, D. (2009). Measuring IS System Service Quality with SERVQUAL : User Perceptions of Relative Importance of the Five SERVPERF Dimensions Informing Science. The international Journal of an Emerging Transdiscipline Volume 12. Retrieved from https://www.researchgate.net/publicat ion/228971695 Measuring is syste $m$ service quality with SERVQUAL Users' perceptions of relative imp ortance of the Five SERVPERF di mensions diakses Tanggal 04 April 2019
Locander, W.B., Hamilton, F., Ladik, D., \& Stuart, J. (2002). Developing a leadership-rich culture : The missing link to creating a market-focused organization, Journal of MarketFocused Management, Vol. 5, pp. 149-163

Lok, P. \& Crawford, J. (1999). The relationship between commitment and organizational culture, subculture, leadership style and job satisfaction in organizational change and development, Leadership \& Organization Development Journal, Vol. 20, No. 7, pp. 365-373

Mangkunegara, A.P. (2006). Evaluasi Kinerja Sumber Daya Manusia. Bandung : Refika Aditama.

Marhaeni, A.A.I.N. (2012). Evaluasi Program Pendidikan. Buku Ajar Mahasiswa Program Pascasarjana. Singaraja : Undiksha.

Peraturan Menteri Riset, Teknologi, dan Pendidikan Tinggi Nomor 14 Tahun 2016 Tentang Organisasi dan Tata Kerja Universitas Pendidikan Ganesha.

Rashid, A.M.Z., Sambasivan, M., \& Johari, J. (2003). The influence of corporate culture and organizational commitment on performance, Journal of Management Development, Vol. 22, No. 8, pp. 708-728

Wirawan. (2011). Evaluasi. Teori, Model, Standar, Aplikasi, dan Profesi. Contoh Aplikasi Program : Pengembangan Sumber Daya Manusia, Program Nasional Pemberdayaan Masyarakat (PNPM) Mandiri Pedesaan, Kurikulum, Perpustakaan, dan Buku Teks. Jakarta : PT. Raja Grafindo Persada. 